\title{
KARTU POP UP TIGA DIMENSI UPAYA MENINGKATKAN PENGETAHUAN DAN PRAKTIK BERKONSTITUSI MELALUI PENDEKATAN GOOD NEWS CLASSMEETING
}

Oleh :

\section{Didit Yoga Sudibyo}

Sekolah Menengah Kejuruan Negeri 2 Kudus

e-mail: diditsudibjappkn@gmail.com

\begin{abstract}
Three Dimensional Pop Up Cards Efforts to Improve Constitutional Knowledge and Practices through the Good News Classmeeting, is the learning of PPKn in the counstitution field which emphasizes three components of PPKn learning, namely civic knowledge, civic skills and civic disposition. Learning with the help of three dimensional media Pop Up makes it interesting and makes it easy to learn articles in the UUD 1945 constitution. Learning with audio video media containing new news in constitutional practice brings students knowledge closer and will form students ready in constitutional practice in Indonesia
\end{abstract}

Keywords: pop up cards, counstitution, good news classmeeting 


\section{PENDAHULUAN}

\section{A. Latar Belakang Masalah}

Pembelajaran PPKn adalah ujung tombak bagi siswa untuk mendapatkan pengetahuan, ketrampilan, serta pembentukan karakter (sikap) dalam mempelajari konstitusi negara kesatuan republik Indonesia.

Hal ini sejalan dengan materi pembelajaran PPKn yang secara garis besar terdiri atas pengetahuan, sikap, dan ketrampilan yang harus dipelajari siswa dalam rangka mencapai kompetensi yang sudah ditentukan.

Ketiga komponen utama PPKn di atas adalah pengetahuan kewarganegaraan (civic knowledge), yang berkaitan dengan isi atau apa yang harus diketahui warganegara ; ketrampilan kewarganegaraan (civic skills) merupakan ketrampilan apa yang seharusnya dimiliki oleh warganegara yang mencakup ketrampilan intelektual dan ketrampilan partisipasi; sikap kewarganegaraan (civic disposition) berkaitan dengan karakter privat dan publik dari warga negara yang perlu dipelihara dan ditingkatkan dalam demokrasi konstitusional.

Pembelajaran PPKn dalam mempelajari konstitusi negara, seringkali tidak sesuai dengan harapan di atas, hal ini karena :

1. Siswa merasa bosan, sebab guru seringkali menanamkan kemampuan untuk mengingat ( pengetahuan ) dengan metode hafalan pasal - pasal dalam Undang - undang Dasar 1945
2. Pembelajaran dengan didominasi oleh ceramah atau pemberian informasi tunggal dari guru. Menjadi kebiasaaan guru untuk bertindak sebagai pemberi informasi, mengembangkan budaya belajar menerima, tanpa partisipasi belajar dari siswa dalam mengkaji pasal pasal Undang - undang Dasar 1945

3. Pembelajaran PPKn yang dirasa abstrak. Pasal - pasal dalam Undang - undang Dasar 1945 hanya sebagai pengetahuan yang abstrak, tidak di perlihatkan dalam praktik bernegara.

4. Kurangnya inovasi media pembelajaran dalam mempelajari konstitusi oleh guru, sehingga kurang menimbulkan minat, dan partisipasi dalam pembelajaran konstitusi.

Permasalahan di atas perlu segera diatasi sehingga pembelajaran tentang konstitusi negara kesatuan republik Indonesia menjadi lebih menarik, berkualitas, dan mampu tercapainya pembelajaran konstitusi negara dalam tiga komponen, yaitu pengetahuan berkonstitusi, ketrampilan berkonstitusi, serta pembentukan karakter ( sikap ) terhadap konstitusi.

Berdasarkan latar belakang masalah di atas penulis penulis menggunakan media pembelajaran berupa kartu pop up tiga dimensi, melalui model pembelajaran good news classmeeting dengan media pembelajaran audio video.

Media kartu pop up tiga dimensi, diharapkan akan mendorong minat siswa dalam memahami pasal - 
pasal dalam Undang - undang Dasar 1945 menjadi lebih menarik dan membantu memudahkan hafalan pasal Undang - undang Dasar 1945.

Model pembelajaran good news classmeeting melalui media audio video merupakan model pembelajaran yang penulis yakin sangat diperlukan dalam pembelajaran PPKn, selain memudahkan siswa mendapatkan pengetahuan lebih menarik, juga mampu mendekatkan siswa dengan praktik berkonstitusi secara langsung, yang muaranya adalah pembentuka sikap warganagera yang sesuai dengan konstitusi.

Tulisan dalam bentuk best practice ini merupakan pengalaman mengajar PPKn selama hamper 15 tahun dalam mendekatkan dan membumikan konstitusi bagi siswa.

\section{B. Rumusan Masalah}

Pada bagian latar belakang di atas, alternatif pemecahan masalah pembelajaran konstitusi negara kesatuan republik Indonesia dalam Pendidikan Kewarganegaraan ( PPKn ) adalah pembelajaran dengan media pop up tiga dimensi menggunakan model good news class meeting melalui media audio video. Pembelajaran menggunakan media pop up tiga dimensi dengan model good news class meeting melalui media audio video tampak dapat memecahkan permasalahan pembelajaran konstitusi negara kesatuan republik Indonesia dalam
Pendidikan Kewarganegaraan (PPKn) sebagai pembelajaran yang lebih menyenangkan dan mengembangkan budaya belajar dari berbagai sumber sehingga menuntut siswa aktif berfikir kritis dan luas, serta pemanfaatan media audio video untuk mendekatkan materi pembelajaran dengan praktik konstitusi dalam negara kesatuan republik Indonesia.

Latar belakang masalah di susun sebagai berikut :

1. Bagaimana prosedur pembelajaran kartu pop up tiga dimensi melalui model good news class meeting dengan media audio video dapat meningkatkan pengetahuan dan praktik berkonstitusi siswa?

2. Bagaimana hasil atau dampak dari pembelajaran kartu pop up tiga dimensi melalui model good news class meeting dengan media audio video dapat meningkatkan pengetahuan dan praktik berkonstitusi siswa?

\section{Tujuan dan Manfaat}

Sesuai masalah yang telah dirumuskan pada bagian sebelumnya, maka karya tulis ini bertujuan untuk : 1. Meningkatkan pengetahuan siswa dalam pembelajaran kontitusi negara kesatuan republik Indonesia.

2. Meningkatkan ketrampilan siswa dalam pembelajaran kontitusi negara kesatuan republik Indonesia. 
3. Membentuk siap siswa dalam pembelajaran kontitusi negara kesatuan republik Indonesia.

Secara praktis, karya tulis ini diharapkan dapat bermanfaat untuk:

1. Bagi Peserta didik,

a. Meningkatnya pengetahuan siswa dalm berkonstitusi

b. Meningkatnya ketrampilan siswa dalam berkonstitusi

c. Membentuk karakter siswa dalam berkonsititusi

2. Bagi Pendidik

a. Memberikan metode pembelajaran inovatif sebagai alternatif yang efektif untuk meningkatkan hasil belajar pada kompetensi dasar sistem hukum dan peradilan internasional bagi para pendidik

b. Mendorong pendidik untuk berinovasi mengembangkan model pembelajaran yang lain.

c. Meningkatkan kinerja pendidik dalam proses pembelajaran.

d. Mendorong pendidik menciptakan media pembelajaran Pendidikan Kewarganegaraan (PPKn) yang menarik dalam pembelajaran.

\section{Bagi Sekolah}

a. Meningkatnya hasil belajar siswa pada mata pelajaran Pendidikan Kewarganegaraan.

b. Meningkatnya peran pendidik dalam proses pembelajaran .

c. Sebagai acuan memperbaiki pembelajaran dengan paradigma baru, yang menerapkan berbagai metode pembelajaran peserta didik aktif.

\section{KAJIAN TEORI}

A. Komponen

\section{Dalam PPKn}

Pembelajaran

Menurut Udin S. Winataputra (Winarno, 2013: 26), komponen pendidikan kewarganegaraan ada tiga yaitu pengetahuan kewarganegaraan (civic knowledge) berkaitan dengan isi atau apa yang harus warga negara ketahui. Ketrampilan kearganegaraan (civic skill) merupakan ketrampilan apa yang seharusnya dimiliki oleh warganegara mencakup ketrampilan intelektual dan partisipasi. Sikap atau karakter (civic disposition) berkaitan dengan karakter privat dan public dari warganegara yang dipelihara dan ditingkatkan dalam demokrasi konstitusional.

Warganegara yang memiliki pengetahuan dan sikap kewarganegaraan menjadi warganegara yang percaya diri ( civic confidence), warganegara yang memiliki pengetahuan dan ketrampilan kewarganegaraan menjadi warganegara yang kompeten (civic competence), warganegara yang memiliki sikap dan ketrampilan kewarganegaraan menjadi warganegara yang komitmen (civic commitment), dan pada akhirnya warganegara yang memiliki pengetahuan, sikap, dan ketrampilan kewarganegaraan akan menjadi warganegara yang cerdas dan baik (smart and good citizienship). 


\section{B. Kartu Pop Up Tiga Dimensi}

Pop up merupakan salah satu bidang kreatif dari paper engeneering yang sekarang makin digemari dan berkembang di Indonesia.

Pop up adalah sebuah buku atau kartu yang ketika di buka bisa menampilkan bentuk tiga dimensi atau timbul.

Dalam pembelajaran konstitusi ini, pop up tiga dimensi berupa kartu yang berwujud gambar tiga dimensi dan berisi gambaran pasal - pasal dari Udang - undang Dasar 1945

Dari gambar tiga dimensi yang muncul dari kartu pop up, akan merangsang minat dan memudahkan hafalan pasal - pasal dalam Undang undang Dasar 1945.

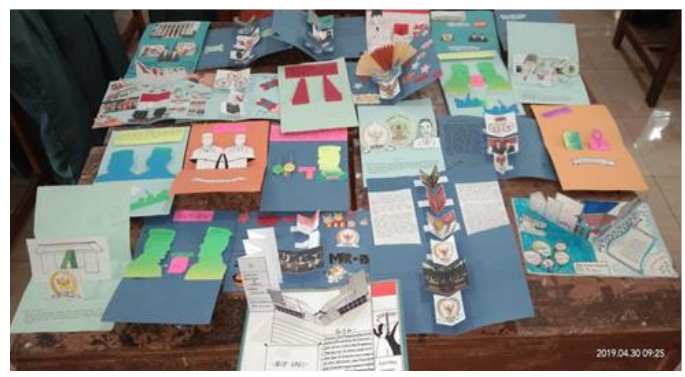

Gambar 1. Kartu Pop Up tiga dimensi

\section{Motivasi belajar dan Hasil Belajar}

Motivasi belajar didefinisikan sebagai dorongan internal dan eksternal pada siswa yang sedang belajar untuk mengadakan perubahan tingkah laku, pada umumnya dengan beberapa indicator atau unsur yang mendukung ( Uno, Hamzah B, 2017 : 23). Indikator motivasi belajar Hamzah B Uno ini ada enam, yaitu (1) adanya hasrat dan keinginan berhasi; (2) adanya dorongan dan kebutuhan dalam belajar; (3) adanya harapan dan cita - cita masa depan ; (4) adanya penghargaan dalam belajar; (5) adanya kegiatan yang menarik dalam belajar; (6) adanya lingkungan yang kondusif dalam belajar (2017 : 23).

Hasil belajar adalah kompetensi atau kemampuan tertentu baik kognitif, afektif maupun psikomotorik yang dicapai atau dikuasi peserta didik setelah mengikuti proses belajar mengajar (Kunandar, $2015: 62$ ).

Merujuk Gagne dalam Agus Suprijono ( 2012 : 5-6 ), hasil belajar berupa :

a. Informasi ferbal yaitu kapabilitas mengungkapkan dalam bentuk bahasa, baik lisan maupun tulisan

b. Ketrampilan intelektual, yaitu kemampuan mempresentasikan konsep dan lambing. Ketrampilan intelektual terdiri dari kemampuan mengategorisasi, kemampuan analitis sintesis fakta-konsep dan mengembangkan prinsip keilmuan.

c. Strategi kognitif yaitu kecakapan menyalurkan dan mengarahkan aktifitas kognitifnya sendiri. Kemampuan ini meliputi penggunaan konsep dan kaidah dalam memecahkan masalah

d. Ketrampilan motorik yaitu kemampuan untukmelakukan serangkaian hasil gerak jasmani

e. Sikap adalah kemampuan menerima atau menolak objek berdasarkan penilaian terhadap objek tersebut 
D. Media Audio Video Dalam Pembelajaran Pendidikan Kewaranegaraan (PPKn)

Guru PPKn dituntut mampu memanfaatkan media pembelajaran Pendidikan Kewarganegaraan (PPKn) yaitu media yang terpilih dan cocok untuk pembelajaran Pendidikan Kewarganegaraan (PPKn). Media pembelajaran dalam Pendidikan Kewarganegaraan (PPKn) harus dapat menstimulus lahirnya proses pembelajaran yang aktif dan kreatif.

Terdapat beberapa pengelompokan media pembelajaran menurut Andi Prastowo ( 2015 : 33 ), sebagai berikut :

a. Media visual ; grafik, diagram, chart, poster, kartun, komik

b. Media audio : tape recorder, laboratorium bahasa, dan seterusnya

c. Poriject still media : slide, overhead projector,

d. Media audio video ; film, televise, video

Dalam karya tulis ini, penulis menggunakan media pembelajaran audio video. Media video sebagai media audio video yang menampilkan gerakan dan suara, samakin popular dimasyarakat. Media inimemberikan pesan yang disajikan bersifat fakta, informative, edukatif, maupun instruksional (Arif S Sadiman, d.k.k, $2014: 74)$.

Dengan penggunaan media audio video, penulis meyakini dapat mendekatkan pengetahuan, praktek dan sikap dalam berkonstitusi bagi warganegara.
Dalam karya tulis ini, penulis meyakini bahwa dengan menggunakan media pembelajaran audio video yang berupa gambar gerak, dan bersuara, berupa kejadian nyata, banyak memiliki kelebihan, diantaranya yaitu dapat menyampaikan pesan secara tepat ke siswa, melibatkan rangsangan penglihatan dan pendengaran siswa, dan menghadirkan kejadian nyata di kelas, sehingga diyakini dapat meningkatkan motivasi peserta didik dalam pembelajaran pembelajaran konstutusi negara.

E. Implementasi

Model Pembelajaran Good News Class Meeting Dalam PPKn

Model pembelajan good News Class Meeting merupakan salah satu model cooperative learning yang mengelompokkan peserta didik sesuai dengan tingkat kemampuan berbedabeda untuk mendorong peserta didik secara aktif bekerja bersama-sama dalam mempelajari dan memahami konsep yang diajarkan serta mempunyai tanggungjawab individu dan kelompok terhadap kuantitas tugas-tugas.

Strategi pembelajaran kooperatif (cooperative learning) merupakan strategi pembelajaran kelompok yang akhir-akhir menjadi perhatian dan dianjurkan para ahli pendidikan untuk digunakan.

Menurut Prof. Udin Winataputra dalam Supandi (2008), model pembelajaran pertemuan kelas berita 
baru (good news class meeting) merupakan model pembelajaran melalui pertemuan kelas guna membahas berita actual, menarik untuk dipelajari dan bermakna bagi siswa yang ada di media massa seperti surat kabar, televisi, radio atau internet.

Langkah-langkah pembelajarannya sebagai berikut :

a. Memilih berita baru yang aktual dan menarik untuk di bahas yang berasal dari media massa seperti surat kabar, berita ditelevisi, radio ataupun internet.

b. Siswa dikelompokkan dan masing masing kelompok bebas membahas dari sudut pandang masing - masing.

c. Tiap

kelompok

mempresentasikan hasil melalui wakil kelompoknya, sedangkan kelompok lain memperhatikan dan merespon bila diperlukan.

d. Guru mengamati dan mengklarifikasi bila tejadi kesalahan

e. Membuat kesepakatan hasil pembahasan kelas.

f. Penutup.

\section{F. Konstitusi}

Menurut K.C Wheare dalam Bagir Manan dan Susi Dwi Harijanti (2015 : x-xi), kata konstitusi digunakan dalam dua arti, pertama untuk menggambarkan keseluruhan system pemerintahan suatu negara, kumpulan aturan yang membentuk dan mengatur pemerintahan, kedua dalam arti sempit merupakan kumpulan aturan penyelenggaraan negara yang dimuat dalam sebuah dokumen.

Konstitusi dan Undang - undang Dasar menunjuk kepada pengertian hukum dasar suatu negara yang mengatur susunan organisasi pemerintahan, menetapkan badanbadan negara dan cara kerja badan tersebut, menetapkan hubungan antara pemerintah dan warga, serta mengawasi pelaksanaan pemerintahan (Taufiqurrohman Syahuri. 2004 : 33).

\section{PEMBAHASAN}

\section{A. Alasan Strategi Pemecahan Masalah yang Dipilih}

Penggunaan pop up tiga dimensi berupa kartu yang berwujud gambar tiga dimensi dari pasal - pasal dalam Udang - undang Dasar 1945 akan merangsang minat dan memudahkan hafalan pasal - pasal dalam Undang undang Dasar 1945.

Bentuk kartu yang memunculkan gambar tiga dimensi menjadikan motivasi belajar meningkat, menghindari rasa bosan serta merangsang hafalan siswa dalam menghafal pasal - pasal dalam Undang - undang Dasar 1945.

Strategi pembelajaran good news clasmeeting merupakan salah pembelajaran kooperatif. Slavin dalam Supandi (2008) mengemukakan dua alasan, pertama, beberapa hasil karya tulis membuktikan bahwa penggunakaan pembelajaran kooperatif dapat meningkatkan prestasi belajar peserta didik sekaligus dapat meningkatkan kemampuan hubungan sosial, menumbuhkan sikap menerima 
kekurangan diri dan orang lain serta dapat meningkatkan harga diri. Kedua, pembelajaran kooperatif dapat merealisasikan kebutuhan peserta didik dalam belajar berfikir, memecahkan masalah dan mengintegrasikan pengetahuan dengan ketrampilan. Dari dua alasan tersebut, maka pembelajaran kooperatif merupakan bentuk pembelajaran yang dapat memperbaiki sistem pembelajaran yang selama ini memiliki kelemahan.

Menurut Prof. Udin Winataputra dalam Supandi ( 2008 ), pembelajaran pertemuan kelas berita baru ( good news class meeting ) merupakan model pembelajaran melalui pertemuan kelas guna membahas berita actual, menarik untuk dipelajari dan bermakna bagi siswa yang ada di media massa seperti surat kabar, televisi, radio atau internet.

\section{B. Tahapan Operasional Dalam Pemecahan Masalah}

Tahapan penerapan kartu Pop up tiga dimensi dalam upaya meningkatkan pengetahuan dan praktik berkonstitusi melalui pendekatan good news classmeeting adalah sebagai berikut :

\section{Belajar berpasangan}

Pada tahap pertama pembelajaran, siswa belajar berpasangan dengan teman sebangkunya untuk mengkaji dan menghafal pasal - pasal dalam UUD 1945.

Tahap pertama ini sebagai bekal awal siswa untuk memahami dan hafal pasal - pasal dalam UUD 1945, untuk diterapkan pada tahap kedua nantinya.
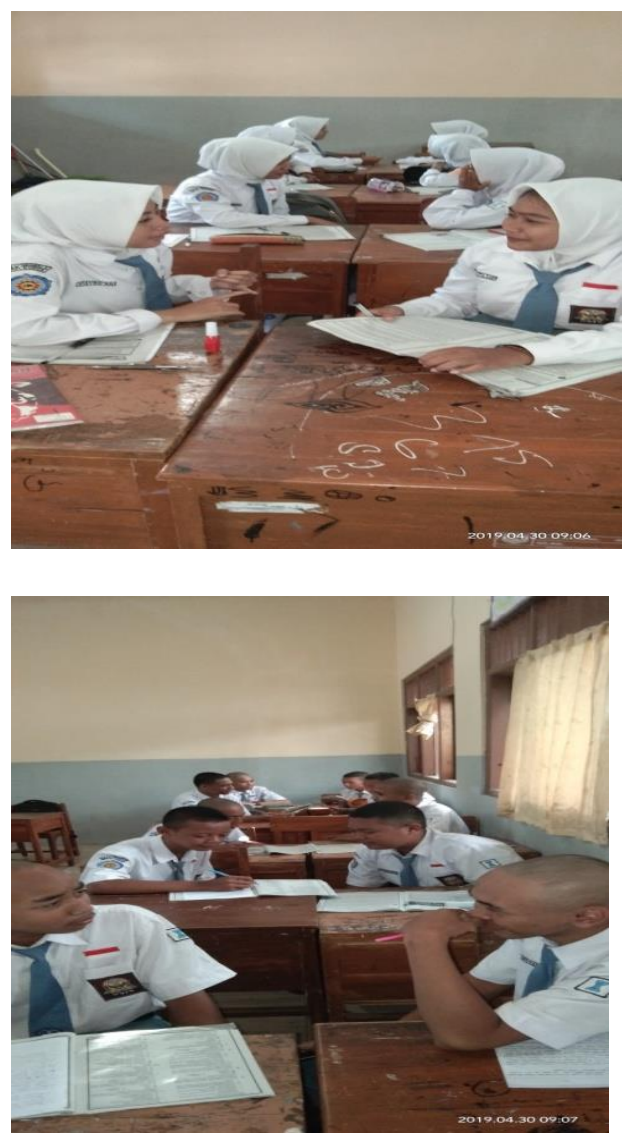

Gambar 2. Diskusi

Berpasangan

2. Belajar berkelompok

Setelah dirasa cukup dalam belajar berpasangan, siswa dibentuk dalam kelompok kecil secara acak, berisi maksimal 6 orang.

Dalam kelompok kecil ini, siswa diberi bantuan media kartu pop up tiga dimensi untuk saling meningkatkan hafalan, pengetahuan, dan berdiskusi terhadap isi pasal UUD 1945 dalam kartu pop up.

Akan tercipta partisipasi dan kerjasama siswa dalam pembelajaran kelompok ini. 

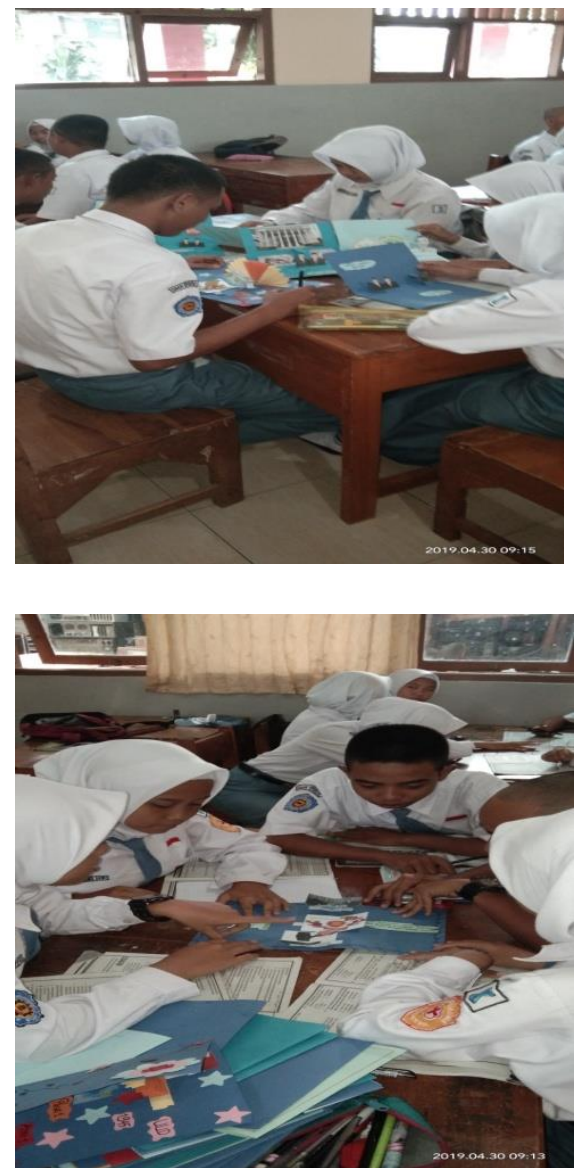

Gambar 3. Diskusi Kelompok

3. Penerapan pendekatan pembelajaran good news classmeeting

Tahapan atau langkah langkah pembelajaran strategi pembelajaran good news class meeting dalam peningkatan pengetahuan dan praktik berkonstitusi siswa melaui media audio video.

Tujuan penggunaan media audio video dengan pemilihan berita televisi terkini, adalah siswa akan mendapatkan pengetahuan yang lebih akan pasal - pasal yang telah dipelajarinya, serta mendapatkan ketrampilan penerapan langsung penggunaan pasal - pasal yang mereka pelajarai dalam diskusi berpasangan atau diskusi kelompok. Sehinggan siswa akan menentukan sikap dari hasil diskusi tayangan berita baru dari televisi tersebut.

Adapun langkah langkah pendekatan pembelajaran good news classmeeting, sebagai berikut :

a. Guru memilih beberapa berita baru yang aktual dan menarik untuk di bahas yang berasal dari berita ditelevisi ataupun internet.

Pemilihan berita dari televisi atau internet dicari yang berwujud audio video dan disesuaikan dengan pasal Undang - undang Dasar 1945 yang akan dibahas.

b. Guru menampilkan beberapa berita aktual kepada siswa. Jumlah berita aktual yang ditayangkan sesuai rencana pembentukan kelompok diskusi yang sudah diperkirakan guru dari jumlah siswa yang ada di kelas. 

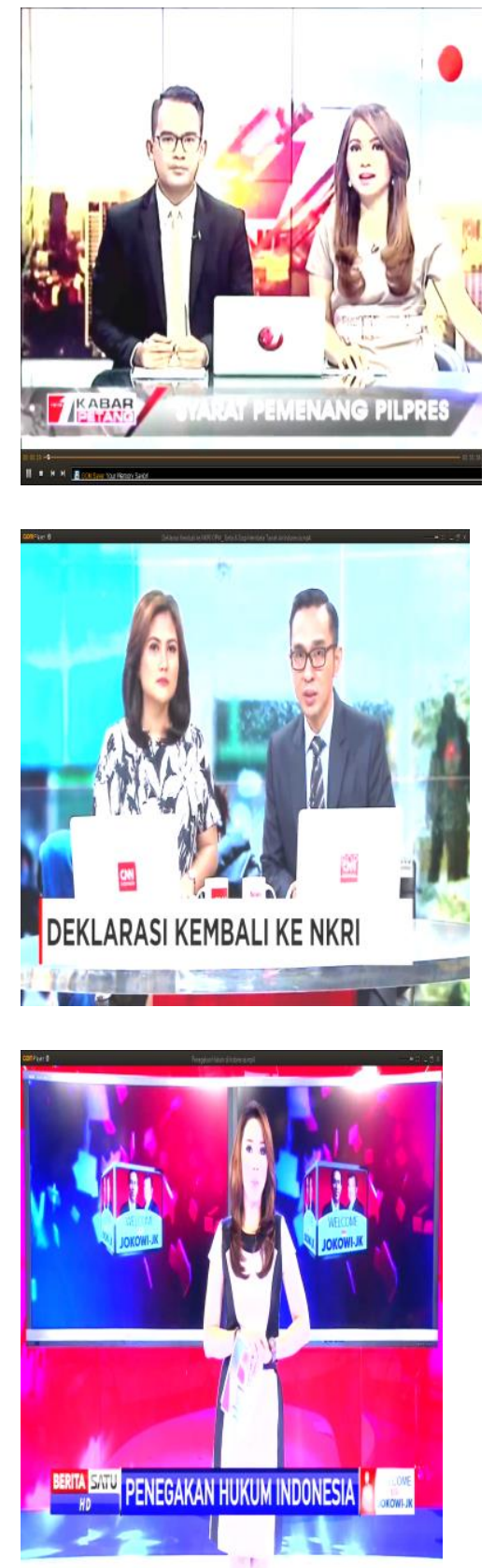

Gambar 4. Beberapa contoh berita dari televisi

c. Tiap kelompok kecil mempresentasikan hasil melalui wakil kelompoknya, sedangkan kelompok lain memperhatikan, mencatat, dan merespon terhadap presentasi kelompok lain dari tayangan berita televisi.

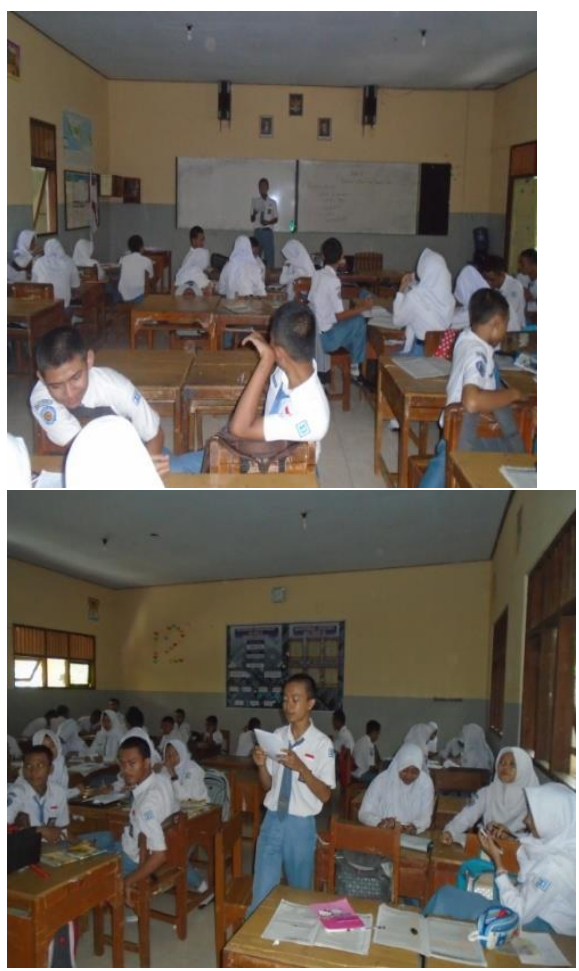

Gambar 5. Presentasi kelompok dan respon dari kelompok lain

d. Guru mengamati dan mengklarifikasi bila tejadi kesalahan

Dalam jalannya diskusi dari hasil penayangan berita televisi, guru mengamati jalannya diskusi dan memberi penegasan apabila keluar dari alur pembahasan.

e. Membuat kesepakatan hasil pembahasan kelas Dari hasil diskusi kelompok dan penayangan berita televisi, guru mengambil kesimpulan akan diskusi konstitusi 

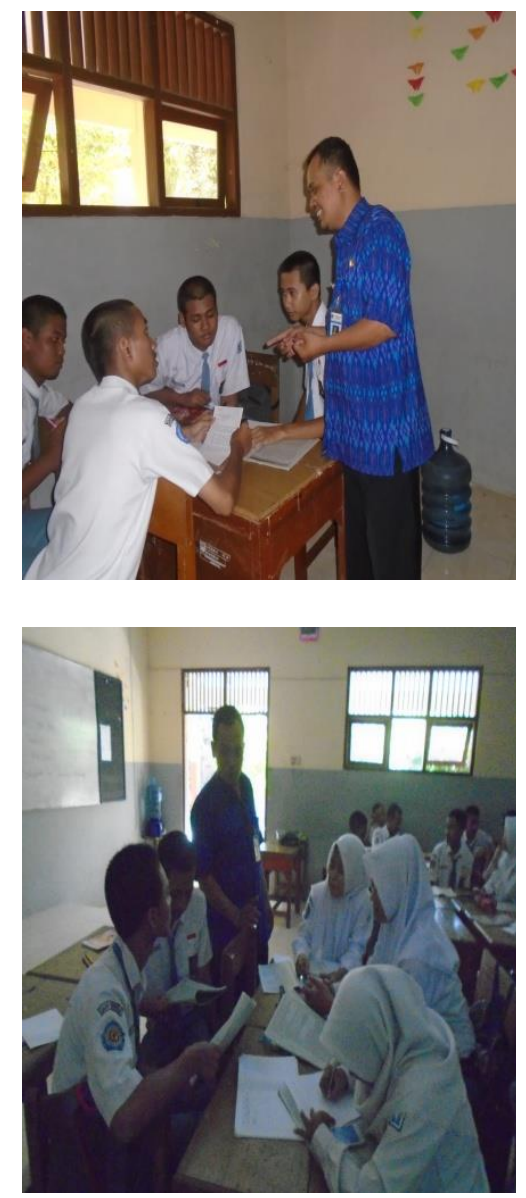

Gambar 6. Guru membimbing dan menyimpulkan diskusi

\section{f. Penutup}

Sebagai penutup diskusi, guru mengarahkan sikap siswa alam pembentukan karakter siswa yang sesuai dengan konstitusi UUD 1945.

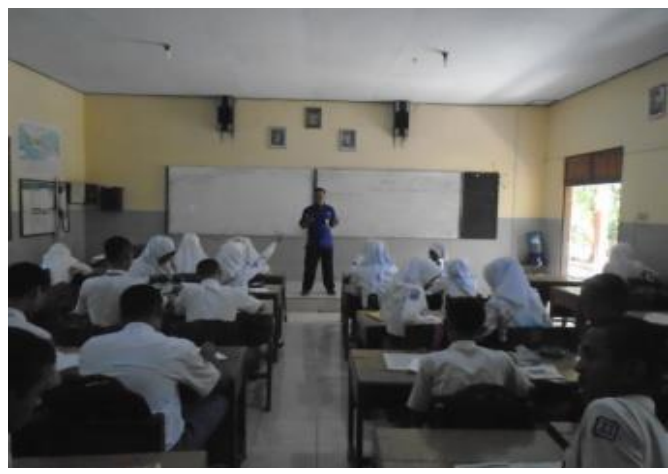

Gambar 7. Penutup diskusi

\section{Hasil yang Dicapai dari Strategi yang Dipilih}

Penggunaan Pop up tiga dimensi dengan strategi pembelajaran good news classmeting melalui media audio video berbasis pendidikan karakter, terbukti dapat meningkatkan pengetahuan dan praktik berkonstitusi siswa sebagai berikiut, diantaranya sebagai berikut:

1. Penggunaan pop up tiga dimensi dan tayangan media audio video yang berisi berita yang sedang banyak dibicarakan, meningkatkan keingintahuan siswa akan isi berita yang ditayangkan. Sehingga suasana belajar akan menjadi menyenangkan dan otomatis minat belajar siswa menjadi meningkat

2. Berita televisi yang ditayangkan melalui media audio, mendekatkan siswa akan ketrampilan berkonstitusi serta menumbuhkan sikap peduli siswa terhadap sosial dan 
lingkungan, cinta tanah air, sikap demokratis, semangat kebangsaan, dan lainnya dalam pendidikan karakter, dengan memahami konstitusi

3. Dengan meningkatnya motivasi belajar siswa, hasil belajar siswa serta praktek berkonstitusi siswa berkonstitusi, akan meningkat pula pada setiap kompetensi dasar lain dalam pembelajaran PPKn dengan strategi pembelajaran good news classmeeting berbasis pendidikan karakter. Penyampaian indikator pembelajaran dituangkan dalam lembar indikator yang akan didikusikan secara berpasangan ataupun dalam kelompok kecil, setelah siswa mengamati serta memberi respon dalam diskusi kelompok

\section{Evaluasi dan Strategi yang Dipilih}

Penggunaan kartu Pop up tiga dimensi dan penerapan strategi pembelajaran good news clasmeeting dalam meningkatkan pengetahuan dan praktik berkonstitusi siswa, sangat bermanfaat bagi siswa. Disamping itu, bermanfaaat pula untuk guru, dan sekolah. Namun ada beberapa hal yang perlu menjadi perhatian dalam penerapannya yang menjadi beberapa kendala dalam pelakasanan pembelajaran dikelas, sebagai berikut :
1. Kendala yang di hadapi

Secara umum kendala yang dihadapai dalam penerapan strategi pembelajaran ini sangat kecil, namun demikain beberapa kendala masih muncul, diantaranya :

a. Pembuatan kartu Pop up yang banyak untuk setiap pasal UUD 1945

b. Ketersediaan alat pembelajaran yang mendukung penggunaan strategi pembelajaran dengan media audio video seringkali tidak tersedia ditiap tiap kelasnya

2. Faktor - faktor pendukung Beberapa faktor pendukung sebagai penguatan pengguanaan kartu Pop up tiga dimensi dengan penerapan starategi pembelajaran good news clasmeeting melaui media audio video diantaranya:

a. Sekolah sangat mendukung terhadap pengembangan pembelajaan kooperatif

b. Siswa sangat antusias dengan pembelajaran kooperatif good news classmeeting melalui media audio video berkarakter

c. Mudahnya mencari pemberitaan di internet terkait pelasanaan konstitusi

3. Alternatif Pengembangan Program pembelajaran disekolah kedepan diarahkan kepada pembelajaran yang lebih 
menarik dan bermakna serta humanis.

Beberapa alternatif pengembangan strategi pembelajaran good news classmeeting antara lain :

a. Mempertajam pendekatan pembelajaran dengan media Pop Up tiga Dimensi dengan penyempurnaan penyempurnaan yang dibutuhkan

b. Mendisplay produk kartu pop up siswa dalam perpustakaan sehingga mampu menginsiprasi adik kelas nya atau seklah lain

c. Pembiasaan pendidikan karakter dalam pembelajaran

d. Pembiasaan peduli bangsa dan cinta tanah air

\section{SIMPULAN DAN SARAN}

\section{A. Simpulan}

Uraian penggunaan kartu Pop up tiga dimensi dengan penerapan strategi pembelajaran good news classmeeting berbasis pendidikan karakter pada bab - bab terdahulu, dapat disimpulkan :

1. Penggunaaankartu pop up dan media pembelajaran audio video terbukti dapat meningkatkan pengetahuan dan ketrampilan berkonstitusi siswa

2. Tergalinya potensi siswa dalam pembelajaran, sehingga dapat tercipta civic knowledge, civic skill, civic dispocition, sehingga terwujud goodcitizienship.

\section{B. Saran}

Berdasarkan pembahasan di atas, penulis menyarankan :

1. Diharapkan guru menumbuhkembangkan

kreativitas diri dalam tugas kependidikannya dengan cara meningkatkan proses dan hasil belajar

2. Untuk mencapai tujuan pendidikan, para guru seharusnya menggunakan paradigm baru dalam memberikan layanan pedagogis dengan cara memperlakukan siswa sebagi subjek didik yang mandiri

3. Setiap satuan pendiidkan untuk mengalokasikan dana dalam RKAS guna memberikan subsidi guru dalam melakukan penelitian tindakan kelas. 


\section{DAFTAR PUSTAKA}

Kunandar. 2015. Penilaian Uatentik ( Penilaian Hasil Belajar Peserta Didik Berdasarkan Kurikulum 2013 ) Suatu Pendekatak Praktis. Jakarta : Raja Grafindo Persada

Manan, Bagir dan Susi Dwi Harijanti. 2015. Memahami Konstitusi Makna dan Aktualisai. Jakarta : Raja Grafindo

Prastowo Andi. 2015. Panduan Kreatif Membuat Bahan Ajar inovatif. Jogjakarta : Diva Press

Sardiman. 2014. Interaksi dan Motivikasi Belajar Mengajar. Jakarta : PT Raja Grafindo Persada

Slamet Sumarto. 2008. Pemanfaatn Media Dalam Pembelajaran. Modul PLPG Sertifikasi Guru Dalam Jabatan Tahun 2008. Jakarta : Kemdikbud.

Sadiman, Arief S, d.k.k. 2014. Media Pendidikan Pengertian, Pengembangan dan Pemanfaatnnya. Jakarta : PT Raja Grafindo Persada.

Supandi. 2008. Peningkatan Profesionalisme Guru Melalui Model Pembelajaran.

Selaya Sulawesi Selatan. Seminar Nasional dan Pelatihan Pembelajaran tanggal 20 maret 2008.

Syahuri, Taufiqurohman. 2004. Hukum Konstitusi. Bogor : Ghalia Indonesia.

Uno, Hamzah B. 2017. Teori Motivasi dan Pengukurannya. Jakarta : Bumi Aksara.

Winarno. 2013. Pembelajaran Pendidikan Kewarganegaraan : Isi, Strategi, dan Penilaian. Jakarta : Bumi Aksara. 